\title{
Increased activity of CHK enhances the radioresistance of MCF-7 breast cancer stem cells
}

\author{
ZHI-XUE YANG* ${ }^{*}$ YI-HUI SUN*, JIAN-GANG HE, HUA CAO and GUO-QIN JIANG \\ Department of General Surgery, The Second Affiliated Hospital of Soochow University, Suzhou, Jiangsu 215004, P.R. China
}

Received October 18, 2014; Accepted July 16, 2015

DOI: $10.3892 / \mathrm{ol} .2015 .3777$

\begin{abstract}
The resistance of breast cancer to radiotherapy remains a major obstacle to successful cancer management. Radiotherapy may result in DNA damage and activate breast cancer stem cells. DNA damage may lead to activation of the checkpoint kinase (CHK) signaling pathway, of which debromohymenialdisine (DBH) is a specific inhibitor. Radiotherapy also increases the expression of phosphorylated CHK1/2 (pCHK1/2) in the breast cancer cell line, MCF-7, in vitro in a dose-dependent manner. $\mathrm{DBH}$ is a relatively stable effective inhibitor that significantly reduces pCHK1/2 expression and MCF-7 proliferation. Low-dose radiotherapy combined with $\mathrm{DBH}$ resulted in a higher MCF-7 inhibition rate compared with high-dose radiation alone. This result indicates that the inhibition of the CHK1/2 signal pathway may significantly reduce DNA damage within radiated cells. Radiotherapy may also regulate the proportion of $\mathrm{CD} 44^{+} / \mathrm{CD} 24^{-} \mathrm{MCF}-7$ cancer stem cells in a dose- and time-dependent manner. However, the stem cell proportion of MCF-7 cells was significantly reduced by treatment with $\mathrm{DBH}$. The inhibition is relatively stable and time dependent. Significant reductions were observed after 3 days of culture $(\mathrm{P}<0.01)$. The results of the present study indicate that the $\mathrm{DBH}$-induced downregulation of $\mathrm{CHK}$ may provide a novel method of enhancing the effect of radiotherapy and reducing stem cell survival in the MCF-7 cell line.
\end{abstract}

\section{Introduction}

Intrinsic or acquired resistance of tumour cells to chemotherapy or radiotherapy remains a major obstacle to successful cancer management. Mechanisms leading to resistance are diverse and poorly defined; however, recent experimental data

Correspondence to: Dr Guo-Qin Jiang, Department of General Surgery, The Second Affiliated Hospital of Soochow University, 1055 Sanxian Road, Suzhou, Jiangsu 215004, P.R. China

E-mail: guoqinjiangcn@163.com

*Contributed equally

Key words: breast cancer, cancer stem cell, CHK1/2, radiotherapy, $\mathrm{DBH}$ support the concept that cancer stem cells (CSCs) are more radioresistant and chemoresistant than their non-stem counterparts (1-3). CSCs display stem-like characteristics and are initially defined as cells endowed with long-term self-renewal and differentiation capacity. In solid tumours, CSCs have been proposed to represent a small proportion of tumour cells; they were also reported to be capable of forming colonies in an in vitro clonogenic assay and tumours in an in vivo assay (4). In breast cancer, CSCs were first described as a population bearing the $\mathrm{ESA}^{+} / \mathrm{CD} 44^{+} / \mathrm{CD} 24^{-}$phenotype, with a 50 -fold higher capability to form tumours in immunodeficient mice and to differentiate into di ${ }^{\circ}$ stinct cellular subtypes $(4,5)$. In breast cancer cell lines, CD $44^{+} / \mathrm{CD} 24^{-}$cells were also described as a subpopulation bearing an invasive capacity and a genetic signature underlying an aggressive phenotype $(6,7)$. Breast CSCs have been characterised by a number of markers, among which $\mathrm{CD} 44^{+} / \mathrm{CD} 24^{-/ \text {low }}$ is the most widely used. However, other markers have also been associated with CSC characteristics, including the presence of a side population (Hoechst 33342 dye exclusion), aldehyde dehydrogenase activity and other prospective markers, including CD133, ESA, PROCR and CXCR4 (8).

DNA damage activates signal transduction pathways referred to as checkpoints, which delay cell cycle progression and allow more time for DNA repair (9). Checkpoints arrest cells in the G1 phase to prevent replication of damaged DNA and in the G2 phase to prevent the segregation of damaged chromosomes during mitosis (9). Increased levels of phosphocholine (PC) is one of the hallmarks of cancer, and numerous studies have established a strong correlation between increased PC and malignant progression $(9,10)$. One of the major causes of high $\mathrm{PC}$ in tumours is the increase in the expression and activity of checkpoint kinase (CHK), a rate-limiting enzyme that phosphorylates and converts choline to PC (10-12). CHK has been previously targeted with novel pharmacological inhibitors $(13,14)$ and posttranscriptional gene silencing $(15)$. The pharmacological inhibition of $\mathrm{CHK}$ cancer cells results in growth arrest and apoptosis (13).

Numerous previous studies have investigated the $\mathrm{CHK}$ pathway in breast cancer cell lines. However, few studies have investigated the $\mathrm{CHK}$ pathway in breast cancer stem cells. Bensimon et al (16) reported that CD24 is associated with the transmission of genomic instability, which leads tumour cells to acquire more aggressive characteristics. The present study aimed to investigate the association between the $\mathrm{CHK}$ 
pathway and the stem cell population of breast cancer cell line, MCF-7. Curman et al (17) reported that debromohymenialdisine (DBH) blocks two major branches of the checkpoint pathway downstream of the serine/threonine kinase ATM, thereby preventing the activation or inhibition of different signal transduction proteins and inhibiting a narrow range of protein kinases in vivo. Therefore, the present study investigated the $\mathrm{DBH}$-inhibited cell cycle $\mathrm{CHK1} / 2$ DNA repair system signal pathway in MCF-7 cancer stem cells to explore the survival impact and the molecular mechanisms of radiotherapy.

\section{Materials and methods}

Cell culture. The MCF-7 human breast cancer cell line was acquired from American Type Culture Collection(Manassas, VA, USA) and cultured in minimal essential media (Sigma-Aldrich, St. Louis, MO, USA) supplemented with $10 \%$ (v/v) fetal bovine serum with 100 units $/ \mathrm{ml}$ penicillin and $100 \mu \mathrm{g} / \mathrm{ml}$ streptomycin (Thermo Fisher Scientific, Inc., Atlanta, GA, USA). The cells were cultured in standard cell culture incubator conditions at $37^{\circ} \mathrm{C}$ in a humidified atmosphere containing $5 \% \mathrm{CO}_{2}$.

Grouping and cell irradiation. Linear accelerator X-ray (6 MV) at dose rate of $2 \mathrm{~Gy} / \mathrm{min}$ was administered with a gantry rotation $180^{\circ}$. Irradiation (IR) was performed through the bottom of the cell culture plate with the source at a distance of $100 \mathrm{~cm}$ (equivalent to $1.5 \mathrm{~cm}$ tissue) in a radiation field size of $10 \times 10 \mathrm{~cm}$. The following experimental groups were established: Control group, A group (DBH), B group (2 Gy IR), B1 group (2 Gy IR + DBH), $\mathrm{C}$ group (5 Gy IR) and $\mathrm{C} 1$ group (5 Gy IR + DBH). DBH (Enzo Life Sciences, Farmingdale, NY, USA) was supplemented with $3 \mu \mathrm{M} / 1$ Dulbecco's Modified Eagle's medium.

Western blot analysis. Total protein from MCF-7 cells was extracted using a cracking buffer $[100 \mathrm{mmol} / 1$ Tris (pH 6.7), $2 \%$ glycerol] containing a protease inhibitor (Sigma-Aldrich) at a 1:200 dilution, resolved on 10\% SDS-PAGE for immunoblot analysis and then incubated using custom-made rabbit polyclonal antibody against human-CHK1/CHK2 (Cell Signalling Technology, Inc., Danvers, MA, USA) at 1:100 dilution in 5\% nonfat dry milk overnight at $4^{\circ} \mathrm{C}$. A mouse monoclonal antibody against human- $\beta$-actin (Sigma-Aldrich) at 1:10,000 was used as control. Appropriate horseradish peroxidase-conjugated secondary antibody, either anti-mouse or anti-rabbit (GE Healthcare Life Sciences, Chalfont, UK), was used at 1:2,500 dilution in milk. Immunoblots were developed using the Super Signal West Pico chemiluminescent substrate kit (Pierce Biotechnology, Inc., Rockford, IL, USA) and images were captured using a Digimax i50 digital camera (Samsung, Suwon, South Korea). The density of immunoblot bands was analyzed using Band Leader software (version 3.0; Band Leader Systems, Inc., Boulder City, NV, USA) as described previously (18).

Methylthiazyl blue tetrazolium bromide (MTT) viability assay. The MCF-7 cells were cultured in vitro in 96-well plates. The concentration was adjusted to $10^{5}$ cells $/ \mathrm{ml}$. A total of $100 \mu \mathrm{l}$ of the cell suspension was added to each well (edge holes were filled with sterile phosphate-buffered solution or PBS to maintain humidity), and maintained at $4.5 \% \mathrm{CO}_{2}, 37^{\circ} \mathrm{C}$. The cells were assigned to the dosing and radiation grouping as above, and cultured for 24,48 or $72 \mathrm{~h}$. The OD value of each well was measured at a detection wavelength of $570 \mathrm{~nm}$ using a microplate reader (Synergy H1 Multi-Mode Reader; BioTek, Shanghai, China), compared with the blank control well (medium, MTT, dimethyl sulfoxide).

IR $(\%)=[(\mathrm{OD}$ control group - OD experimental group) $/ \mathrm{OD}$ of control group] x 100 .

Flow cytometry. The proportion of the stem cell-like MCF-7 cells was investigated following radiotherapy. Cells were treated with 0,2 and 5 Gy IR. All groups were cultured for $48 \mathrm{~h}$. The MCF-7 cell culture was digested with $0.25 \%$ trypsin to produce a single cell suspension. Digestion was terminated by adding a culture solution of $10 \%$ fetal calf serum. The cells were centrifuged at $200 \mathrm{x}$ g for $10 \mathrm{~min}$ and then washed twice with PBS and the cell concentration was adjusted to $1 \times 10^{6}$ cells $/ \mathrm{ml}$. Approximately $40 \mu \mathrm{l}$ of the cell suspension was placed in a flow cytometry test tube, added with $0.5 \%$ bovine serum albumin (BSA) was added and then the samples were incubated at room temperature for $30 \mathrm{~min}$. Approximately $20 \mu \mathrm{l}$ of CD24-FITC mouse monoclonal conjugated antibody (1:300) was added to CD44-PE mouse monoclonal antibody (1:300; R\&D Systems China Co., Ltd., Shanghai, China) and then incubated in the dark at room temperature for $20 \mathrm{~min}$. The cells were washed twice with PBS (3 ml) to remove excess antibodies. The cells were then re-suspended in $3 \mathrm{ml}$ PBS and analysed using a BD Accuri $^{\text {TM }}$ C6 flow cytometer (Becton Dickinson, Franklin Lakes, NJ, USA) at $488 \mathrm{~nm} / 520 \mathrm{~nm}$. Three parallel samples were run (Separate blank, CD44-PE, CD24-FITC control tube).

Direct immunofluorescence microscopy. MCF-7 cells in the logarithmic growth phase were seeded on sterilised glass slides in a 24 -well cell culture plate $(50,000$ cells/well). The following groups were established: Control group, A group (DBH), B group (2 Gy IR), B1 group (2 Gy IR + DBH), C group (5 Gy IR) and $\mathrm{Cl}$ group (5 Gy IR + DBH). Adherent cells that survived were subjected to 5 Gy radiation and then cultured for 1 to 8 days. Parallel experiments were performed in triplicate. Following incubation, the cells were washed twice with PBS, cooled to $4^{\circ} \mathrm{C}$, and then fixed with methanol for $10 \mathrm{~min}$. The slides were washed 4 times with PBS and then $1 \%$ BSA blocking solution was added dropwise at $4^{\circ} \mathrm{C}$ for $1 \mathrm{~h}$. The slides were washed 4 times with PBS. Mouse anti-human PE-CD44-IgG (red) and mouse anti-human FITC-CD24-IgG (Green) at 1:200 dilution were added dropwise to the samples. The samples were then incubated in the dark for $60 \mathrm{~min}$. Subsequently, the samples were washed one to two times with PBS ( $\mathrm{pH} 7.2$ to 7.4). The cells were stained with $20 \mu 1$ DAPI (Sigma-Aldrich) by dropwise addition at ambient temperature in the dark. After allowing to stand for $10 \mathrm{~min}$, the slides were washed with PBS. Anti-fade mounting medium (Beyotime Institute of Biotechnology, Shanghai, China) was added dropwise. The cells were observed by fluorescence microscopy (IX51; Olympus Co., Ltd., Shanghai, China). Three independent experiments were performed, the results were counted and the means were calculated.

Statistical analysis. Statistical analysis was performed using SPSS software, version 13.0 (SPSS, Inc., Chicago, IL, USA). All data are presented as the mean \pm standard deviation and 


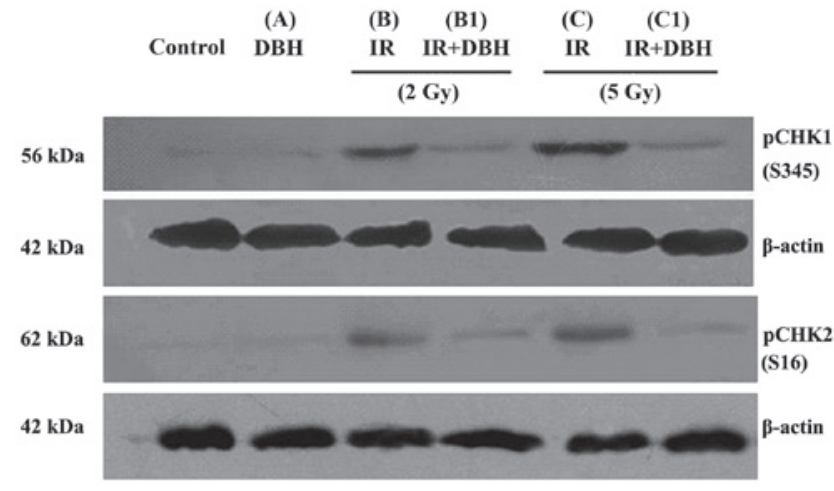

Figure 1. The pCHK1 and $\mathrm{pCHK} 2$ protein expression influenced by radiotherapy and DBH assessed by western blot analysis. pCHK1/2, phosphorylated checkpoint kinase 1/2; IR, irradiation; DBH, debromohymenialdisine.

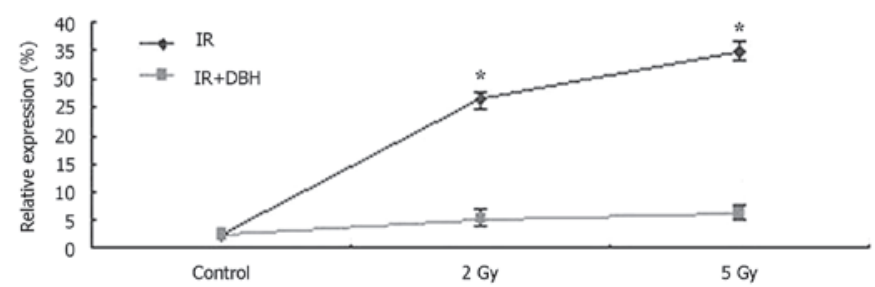

Figure 2. The relative expression of $\mathrm{pCHK} 1$ protein influenced by increasing doses of radiotherapy and DBH. Gel electrophoresis image was analyzed by Bandleader software (3.0 version). pCHK1 protein expression levels in the control, (B), and (C) groups were $1.48 \pm 0.11,26.29 \pm 0.24$, and $39.72 \pm 1.45 \%$. Following radiotherapy with $\mathrm{DBH}$, a difference in pCHK1 expression was observed between the B1 group $(5.46 \pm 1.45 \%)$ and $\mathrm{C} 1$ group $(6.02 \pm 1.39 \%$; $\mathrm{P}<0.05)$. Parallel experiments were performed in triplicate. $\mathrm{P}<0.05$ and $\mathrm{P}<0.01$ were considered to indicate statistical difference and statistically significant difference, respectively. ${ }^{\text {}} \mathrm{P}<0.05$. pCHK1/2, phosphorylated checkpoint kinase 1/2; IR, irradiation; DBH, debromohymenialdisine.

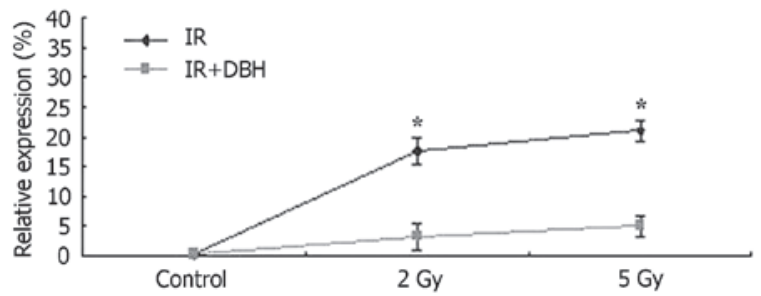

Figure 3. The relative expression of $\mathrm{pCHK} 2$ protein influenced by different dose of radiotherapy and DBH. pCHK2 protein level exhibited the similar trend as Fig. 2. Experimental method, comparing groups, repeating times are the same as Fig. $2 .{ }^{*} \mathrm{P}<0.01$ was considered to indicate statistical difference. pCHK1/2, phosphorylated checkpoint kinase 1/2; IR, irradiation; DBH, debromohymenialdisine.

one-way analysis of variance and Dunnett's T3 post test were used to determine the statistical significance. Differences between groups were analyzed using two-sided $t$-tests. $\mathrm{P}<0.05$ and $\mathrm{P}<0.01$ were considered to indicate a statistical difference and statistically significant difference, respectively.

\section{Results}

Radiation may result in DNA damage and increase the pCHK1/CHK2 level in breast cancer cells, DBH inhibits

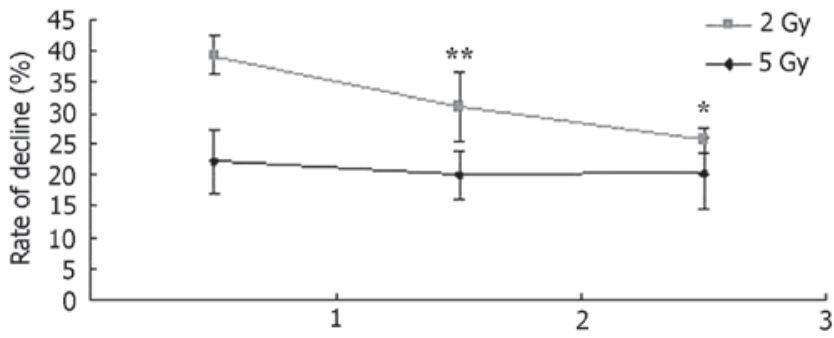

Figure 4. The inhibitive proportion of different dose of radiotherapy with/without DBH at different culture times. The inhibition rate increased in Group B1 cells were treated with the low dose radiation and application of $3 \mu \mathrm{M} \mathrm{DBH}$ at the same time. The prolong time incubation with DBH contributed to the increase of inhibitive rate after radiotherapy. Data are presented as mean \pm standard deviation $( \pm \mathrm{s}, \mathrm{n}=3)$. ${ }^{* *} \mathrm{P}<0.05$ and ${ }^{*} \mathrm{P}<0.01$ were considered to indicate statistical difference and statistically significant difference, respectively.

the phosphorylation of cell cycle checkpoint kinase CHK1/2 specifically (13-15). In the present study, western blot analysis demonstrated that $\mathrm{pCHK} 1 / 2$ was markedly increased following $24 \mathrm{~h}$ of radiotherapy with either low dose radiation at 2 Gy or high dose radiation at 5 Gy, as presented in Fig. 1 (Bandleader calculation). The pCHK1 protein levels in the control, B (treated with 2 Gy radiation dose) and C (treated with 5 Gy radiation dose) groups were $1.48 \pm 0.11,26.29 \pm 0.24$, and $39.72 \pm 1.45 \%$, respectively. pCHK2 protein level exhibited the same trend. CHK protein was therefore significantly activated in the $24 \mathrm{~h}$ following radiation. In addition, the activation of $\mathrm{CHK}$ proteins by radiation was dose-dependent in the MCF-7 cell line. DBH had no effect on the activation of $\mathrm{CHK}$ protein in the MCF-7 cell line not treated with radiation. However it appeared to serve a role in the MCF-7 cells which were treated by radiation. The $\mathrm{pCHK} 1$ protein compared with actin in the B1 group (2 Gy radiation and $3 \mu \mathrm{M}$ DHB application) and $\mathrm{C} 1$ group (5 Gy radiation and $3 \mu \mathrm{M}$ DHB application) were $5.46 \pm 1.45 \%$ and $6.02 \pm 1.39 \%$, respectively $(\mathrm{P}<0.05)$ (Fig. 2). pCHK1 protein expression markedly reduced following low or high dose radiation when DHB was also applied. With low dose radiation, the $\mathrm{pCHK} 1$ protein was reduced by $79.23 \pm 3.80 \%$ (2 Gy) compared with B group. With high dose radiation, the pCHK1 protein was reduced by $82.67 \pm 4.19 \%$ (5 Gy) compared with C group (Fig. 3).

DBH inhibits $M C F-7$ proliferation following radiotherapy. Methylthiazyl blue tetrazolium bromide (MTT) viability assay is presented in Table I: No significant difference was observed in the inhibition rate of breast cancer MCF-7 cells in the simple dosing DBH group compared with the control group $(\mathrm{P}>0.05)$. This result indicates that the experimental DBH drug concentration $(3 \mu \mathrm{M})$ had no significant cytotoxicity. Following 24,48 , and $72 \mathrm{~h}$ of radiotherapy, the inhibition rates of the B group were $21.43 \pm 3.19 \%, 36.36 \pm 5.47 \%$, and $47.79 \pm 9.16 \%$, respectively. After 24,48 , and 72 h of radiotherapy, the inhibition rates of the B1 group were 60.71 \pm 5.23 , $67.27 \pm 3.74$, and $73.45 \pm 5.72 \%$, respectively. The inhibition rate of the $\mathrm{C} 1$ group was $65.18 \pm 6.41,72.73 \pm 10.18,80.53 \pm 9.16 \%$, which was increased compared with the B1 group. These results indicated that the inhibition rate of $\mathrm{MCF}-7$ was time and dose dependent. In addition, DBH may increase the sensi- 
Table I. Inhibition of MCF-7 by DBH after radiotherapy.

\begin{tabular}{lccccccc}
\hline & \multicolumn{3}{c}{ Exposure time } & & \multicolumn{3}{c}{ Inhibitive proportion (\%) } \\
\cline { 2 - 3 } Groups & $24 \mathrm{~h}$ & $48 \mathrm{~h}$ & $72 \mathrm{~h}$ & & $24 \mathrm{~h}$ & $48 \mathrm{~h}$ & $72 \mathrm{~h}$ \\
\hline Control & $1.12 \pm 0.05$ & $1.10 \pm 0.07$ & $1.13 \pm 0.03$ & & 0 & 0 & 0 \\
$\mathrm{~A}$ & $1.08 \pm 0.06$ & $1.15 \pm 0.08$ & $1.10 \pm 0.03$ & & $3.57 \pm 0.21$ & $4.54 \pm 0.23$ & $2.65 \pm 0.35$ \\
$\mathrm{~B}$ & $0.88 \pm 0.07$ & $0.70 \pm 0.03$ & $0.59 \pm 0.04$ & & $21.43 \pm 3.19$ & $36.36 \pm 5.47$ & $47.79 \pm 9.16$ \\
B1 $^{\text {a }}$ & $0.44 \pm 0.03$ & $0.36 \pm 0.02$ & $0.30 \pm 0.08$ & & $60.71 \pm 5.23$ & $67.27 \pm 3.74$ & $73.45 \pm 5.72$ \\
$\mathrm{C}$ & $0.64 \pm 0.05$ & $0.52 \pm 0.02$ & $0.45 \pm 0.01$ & & $42.86 \pm 2.09$ & $52.72 \pm 8.68$ & $60.18 \pm 7.81$ \\
$\mathrm{C}^{\mathrm{b}}{ }^{\mathrm{b}}$ & $0.39 \pm 0.02$ & $0.30 \pm 0.06$ & $0.22 \pm 0.04$ & & $65.18 \pm 6.41$ & $72.73 \pm 10.18$ & $80.53 \pm 9.16$ \\
\hline
\end{tabular}

${ }^{\text {a }} \mathrm{P}<0.05$ vs. group B (2 Gy IR alone); ${ }^{\text {}} \mathrm{P}<0.01$ vs. group C (5 Gy IR alone). IR, irradiation; DBH, debromohymenialdisine.
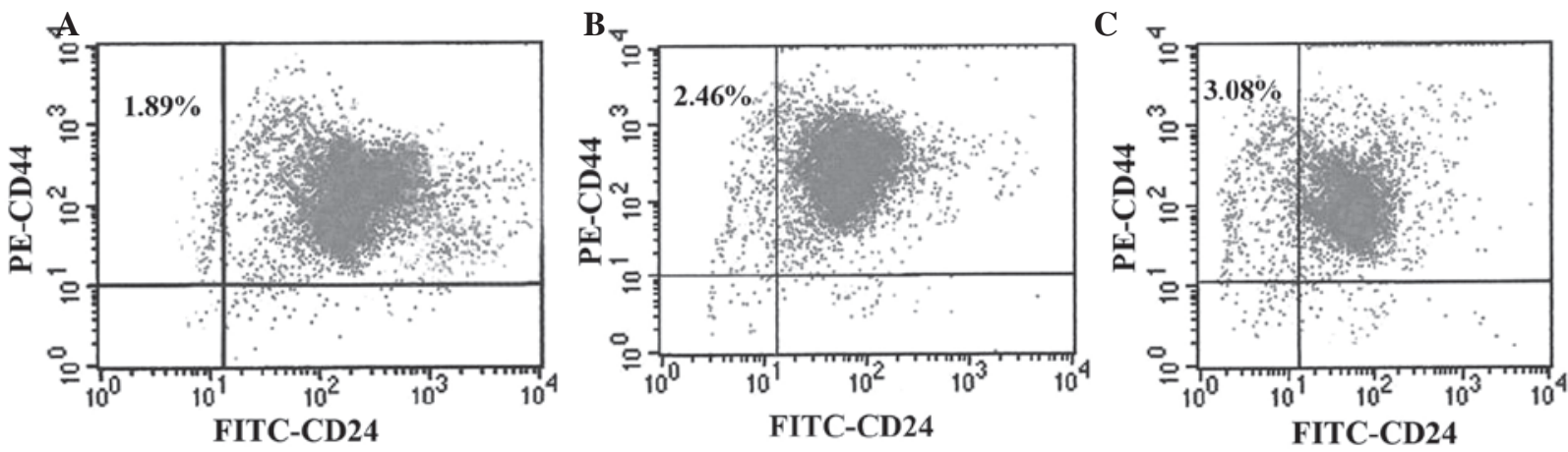

Figure 5. The proportion of $\mathrm{CD} 44^{+} \mathrm{CD} 24^{-} \mathrm{MCF}-7$ cells at different doses radiotherapy. (A) Prior to radiotherapy $\mathrm{CD}^{-} 4^{+} \mathrm{CD} 24^{-}$cells comprised $1.89 \pm 0.20 \%$ of the total; (B) following $2 \mathrm{~Gy}$ radiotherapy, $\mathrm{CD} 44^{+} \mathrm{CD} 24^{-}$cells comprised $2.46 \pm 0.27 \%^{\mathrm{a}}$. (C) following 5 Gy radiotherapy, $\mathrm{CD} 44^{+} \mathrm{CD} 24^{-}$comprised $3.08 \pm 0.21 \%^{\mathrm{b}}$. Data are presented as the mean \pm standard deviation $( \pm \mathrm{s}, \mathrm{n}=3)$. ${ }^{\mathrm{a}} \mathrm{P}<0.05$ and ${ }^{\mathrm{b}} \mathrm{P}<0.01$ vs. control.

tivity of radiotherapy by inhibiting the CHK signal pathway. The percentage of the downregulation of inhibition of MCF-7 cells between the $\mathrm{B} 1$ and $\mathrm{C} 1$ groups and their control groups $\mathrm{B}$ and $\mathrm{C}$ were calculated and compared at different time periods (Fig. 4). The inhibition rate increased in Group B1, where cells were simultaneously treated with the low dose radiation and application of $3 \mu \mathrm{M}$ DBH. In group B1, increasing the incubation time with $\mathrm{DBH}$ contributed to the increase in inhibition rate following radiotherapy. However, the same trend was not observed in Group C1, the inhibition rate in Group C1 was not statistically different at longer culture time, when cells were simultaneously treated with high dose radiation and application of $3 \mu \mathrm{M}$ DBH $(\mathrm{P}>0.05)$. Therefore, $\mathrm{DBH}$ inhibited the survival of MCF-7 cells following low-dose radiation and the inhibition rate becomes more effective as the incubation time with DBH is increased.

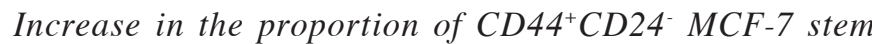
cells following radiotherapy. The flow cytometry excitation wavelength was $488 \mathrm{~nm}$. The PE and FITC emitted light was collected at 525 and $575 \mathrm{~nm}$, respectively. The results demonstrated that the breast cancer MCF-7 cell line was composed of four subpopulations: CD $44^{+} \mathrm{CD} 24^{+}(95.04 \pm 2.15 \%)$, CD $44^{+} \mathrm{CD}^{2} 4^{-}(1.89 \pm 0.20 \%), \mathrm{CD}^{-} 4^{-} \mathrm{CD} 24^{+}(1.65 \pm 0.33 \%)$, and $\mathrm{CD}^{-} 4^{-\mathrm{CD}} 24^{-}(1.41 \pm 0.17 \%)$. The majority of the $\mathrm{MCF}-7$ cell line were $\mathrm{CD} 44^{+} \mathrm{CD} 24^{+}$cells. $\mathrm{CD} 44^{+} \mathrm{CD} 24^{-}$cells were rare, and may be regarded as stem cells in $\mathrm{MCF}-7$ cell line (Fig. 5A). Following irradiation, the $\mathrm{CD} 44^{+} \mathrm{CD} 24^{-}$ratio in the 2 Gy irradiation group increased to $2.46 \pm 0.27 \%$ (Fig. 5B), and that of the $5 \mathrm{~Gy}$ irradiation group reached $3.08 \pm 0.21 \%$ (Fig. 5C). The results demonstrated that exposure to radiation results in the increase of $\mathrm{CD} 44^{+} \mathrm{CD} 24^{-}$cell population in the MCF-7 cell line. The ratio of $\mathrm{CD}_{4} 4^{+} \mathrm{CD} 24^{-} \mathrm{MCF}-7$ cell line increased gradually with increasing radiation dose $(\mathrm{P}<0.05)$.

Increase in $\mathrm{CD}^{4} 4^{+} \mathrm{CD} 24^{-} \mathrm{MCF}-7$ cell population following radiotherapy was inhibited by $D B H$. In the direct immunofluorescence microscopy, PE-CD44-IgG and FITC-CD24-IgG were red and green, respectively. The strength of CD44 and CD24 expression levels on the cell membrane can be determined. CD $44^{+} \mathrm{CD} 24^{+}$had yellow fluorescence, $\mathrm{CD} 44^{+} \mathrm{CD} 24^{-}$had red, CD $44^{-} \mathrm{CD} 24^{+}$had green, and CD44-CD24- only showed deep blue nuclear DAPI fluorescence. In the control group and the dosing group, the CD $44^{+} \mathrm{CD} 24^{-}$cell ratio was $1.89 \pm 0.20 \%$, and $\mathrm{CD} 44^{+} \mathrm{CD} 24^{+}$ cells accounted for $95.04 \pm 2.15 \%$ of the total cell population. The ratio of $\mathrm{CD} 44^{+} \mathrm{CD} 24^{-}$cancer stem cells significantly increased following 5 Gy irradiation, and the activation of CD $44^{+} \mathrm{CD} 24^{-}$cells was time dependent (Fig. 6). In the DBH with irradiation group, the proportion of CD $44^{+} \mathrm{CD} 24^{-}$cancer stem cells was slightly increased in the first 3 days and then reduced and remained stable at $3.73 \pm 0.35 \%$. However, the 


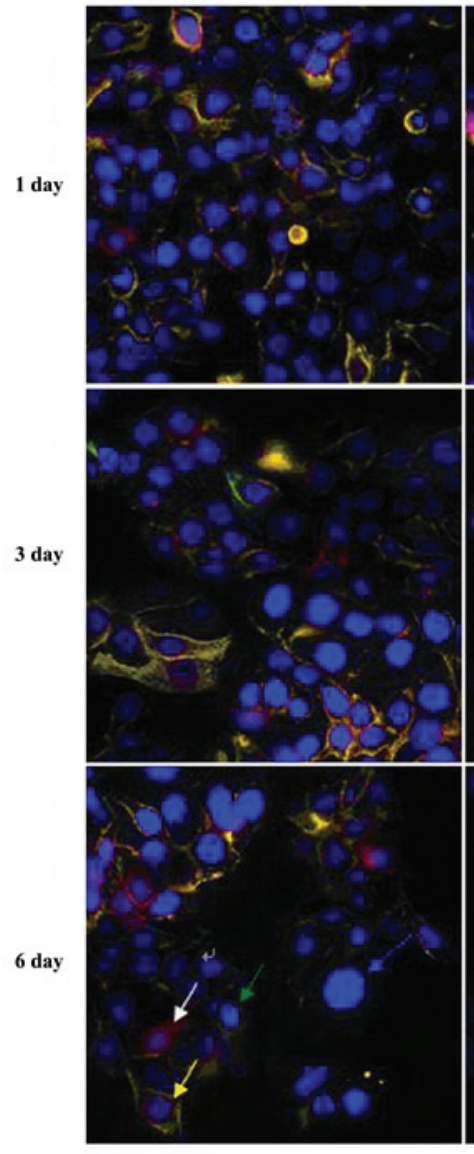

IR (5Gy)
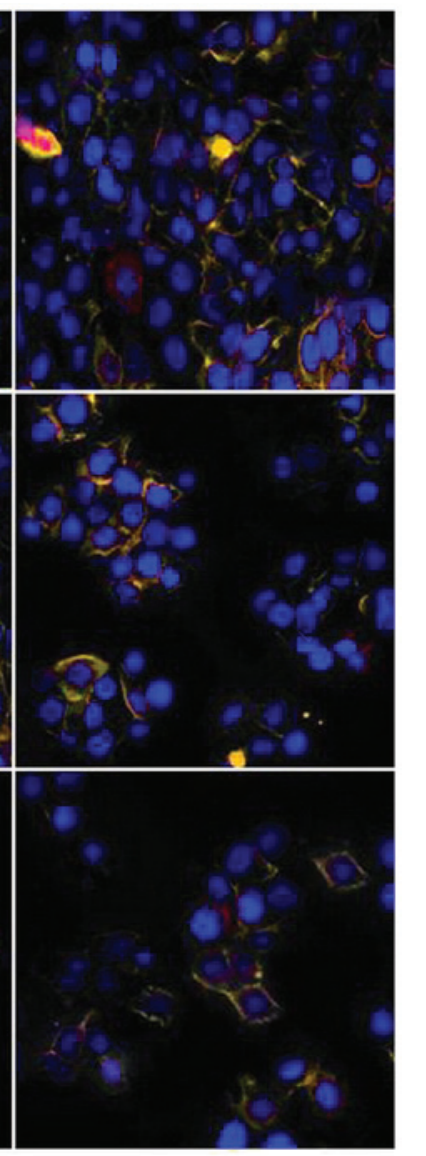

DBH+IR (5Gy)
Figure $6 . \mathrm{CD} 44^{+} \mathrm{CD} 24$ - proportion of $\mathrm{MCF}-7$ cells at different time points following radiotherapy with/without $\mathrm{DBH}$. The white arrows indicate the CD $44^{+} \mathrm{CD} 24^{-}$stem cell population of MCF-7 cells under direct immunofluorescence microscopy (magnification, x600). IR, irradiation; DBH, debromohymenialdisine.

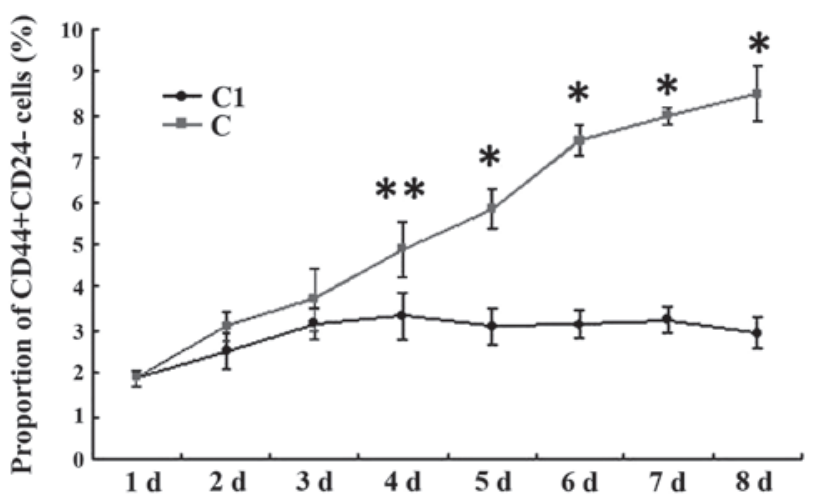

Figure 7. The proportion of $\mathrm{CD} 44^{+} \mathrm{CD} 24^{-}$cells activated by radiotherapy at different culture times with/without $\mathrm{DBH}$. In the $\mathrm{C} 1$ group, the proportion of $\mathrm{CD} 44^{+} \mathrm{CD} 24-$ cancer stem cells was slightly increased in the first 3 days then reduced and remained at $3.73 \pm 0.35 \%$ stably. The proportion of CD $44^{+} \mathrm{CD} 24$ cells in the $\mathrm{C} 1$ group was always lower compared with the $\mathrm{C}$ group, with a significant difference between the two groups observed on days $4-8$. ${ }^{*} \mathrm{P}<0.01$ and ${ }^{* *} \mathrm{P}<0.05$ were considered to indicate statistical difference. $\mathrm{C} 1$ group, $(\mathrm{IR} \pm \mathrm{DBH}) ; \mathrm{C}$ group (IR); IR, irradiation; DBH, debromohymenialdisine.

proportion of $\mathrm{CD} 44^{+} \mathrm{CD} 24^{-}$in the $\mathrm{DBH}$ with irradiation group was always reduced compared with the irradiation group alone (Fig. 7). DBH may inhibit the CHK signal pathway therefore inhibiting the breast cancer stem cells from being activated by the radiotherapy.

\section{Discussion}

Radiotherapy may result in damaged DNA. It has an important role in breast cancer treatment. However, radiation resistance of breast cancer remains a challenge. Previous studies have demonstrated the mechanism of radiation resistance of cancer cells in a number of aspects, including the level of reactive oxygen species, histone H2AX phosphorylation of the EGFR signalling pathway activation (19), Notch pathway activation (20), Wnt- $\beta$-catenin of surviving signal activation $(21,22)$, the hypoxic microenvironment (23) and the cell cycle checkpoint control of cell proliferation cycle, which has an important function in radiotherapy response (24). The CHKl/2 downstream effector gene ATM/ATR, located on the cell cycle checkpoint activation pathway terminal activates DNA damage detection point when DNA is damaged. The activation is regulated by cell division cycle protein $25 \mathrm{~A} / \mathrm{B} / \mathrm{C}(\mathrm{CDC} 25 \mathrm{~A} / \mathrm{B} / \mathrm{C})$ and the 14-3-3 proteins. $\mathrm{CHKl}$ as a cell cycle checkpoint kinase has a protective role in the $\mathrm{M}$ phase checkpoint; it also alleviates the segregation of damaged chromosomes during mitosis, thereby reducing cell death (25). CHK2 is expressed throughout the cell cycle but only when the double-strand break upstream protein ATM is activated. The activation of breast cancer gene 1 (breast cancer 1, BRCAl) by CHK2, in addition to the promotion of BRCA2 expression, is involved in homologous recombination, nucleotide excision repair, and DNA repair (26-28). CHK1 and CHK2 are activated by phosphorylation following DNA damage resulting from drugs, ionising radiation (IR), and ultraviolet radiation (9). ATM and ATR occupy an important position in radiotherapy-induced DNA repair.

Focusing radiotherapy of breast cancer cells in the cell cycle checkpoint resistance results in enhanced DNA repair capacity. Therefore, agents that block DNA damage-induced cell cycle arrest and reduce DNA repair efficiency may potentially sensitize breast cancer cells to radiotherapy. $\mathrm{DBH}$ is sponge extract isolated from marine organisms containing pyrrole seven-membered ring lactam alkaloid. DBH inhibits the activation of CHK1 and CHK2 (17). Others, such as 17-DMAG of CHK1 inhibitors (29), UCN-01 (CHK2 inhibitor) (30) and other drugs had no for both CHK 1/2. The overlapping functions of $\mathrm{CHK} 1$ and $\mathrm{CHK} 2$ enhance the ability of tumour cells to protect themselves, and both can act on $\mathrm{Cdc} 25 \mathrm{C}$. They have functions on the $\mathrm{S}$ and $\mathrm{G} 2$ phase detection point, demonstrating mutually complementary roles $(31,32)$. Therefore, selecting both $\mathrm{CHK} 1$ and $\mathrm{CHK} 2$ as therapeutic targets is more reasonable than either of the two alone.

In the present study, $\mathrm{pCHK} 1 / 2$ in the breast cancer MCF-7 cell line radiotherapy following $24 \mathrm{~h}$ was detected by western blot analysis. pCHK1/2 expression level significantly increased with increasing radiation dose. Therefore, the breast cancer cell cycle checkpoint pathway reaction enhanced DNA damage repair, thereby weakening the sensitivity to radiotherapy. When DBH was coupled with radiotherapy, pCHK1 and $\mathrm{pCHK} 2$ were downregulated $(\mathrm{P}<0.01)$, and the radiation dose was positively correlated with this effect $(\mathrm{P}<0.05)$. The downregulation of $\mathrm{pCHK} 1 / 2$ had no significant correlation 
with radiotherapy prior to and following DBH treatment, which indicates that DBH as an efficacy inhibitor is relatively stable. MCF-7 cell proliferation was also determined using an MTT assay following radiotherapy. The inhibition of MCF-7 cell proliferation had the same trend as was observed for pCHK1/2 expression levels. Low-dose radiotherapy combined with DBH achieved a higher MCF-7 inhibition rate compared with high-dose radiation alone $(\mathrm{P}<0.01)$. This finding indicates that the inhibition of the CHK $1 / 2$ molecule signalling pathway reduces cell DNA damage repair.

Stem cells have the capacity for self-renewal, unlimited proliferation and differentiation. By comparing stem cells and tumour cell subsets in cancer research, similarities were observed between the two, including self-renewal and proliferation capacity; Notch, Wnt, Sonic hedgehog (Shh) and Bmi21 signalling pathways involved in cell growth and development; and their ability to migrate or transfer (33). As such, the CSC hypothesis was proposed, which indicated that the presence of a small proportion of tumour cells in the tumour tissue has a significant role in initiating tumour formation and maintaining tumour growth. These cells also have a decisive role, self-renewal capacity and differentiation potential source of malignant tumour growth, metastasis and recurrence. Al-Hajj et al (5) isolated a CD $44^{+} \mathrm{CD} 24^{-1 \text { low }}$-population of cells from the tissue of breast cancer patients. Following transplantation of $\sim 200$ of these cells in non-obese diabetic/severe combined immunodeficient mice formed $\sim 1 \mathrm{~cm}$ tumours in 5-6 months. By contrast, no tumourigenic or low tumourigenic ability was observed in the other MCF-7 cell subtypes. Compared with the unsorted cells, the $\mathrm{CD} 44^{+} \mathrm{CD} 24^{-/ \text {low }}$ and ESA $^{+}$lin population cells exhibited a 50 -fold increase in tumourigenic ability. The resulting tumour contained the same separable $\mathrm{CD} 44^{+} \mathrm{CD} 24^{-} /^{\text {low }} \mathrm{ESA}^{+}$lin cancer cells, with the same tumourigenic ability, which for the first time confirmed the existence of breast cancer stem cells. Fillmore et al (1) reaffirmed the phenotype of $\mathrm{CD} 44^{+} \mathrm{CD} 24^{-} \mathrm{MCF}-7$ cells having CSC characteristics.

The experiments of the present study further explored the association between the $\mathrm{CD} 44^{+} \mathrm{CD} 24^{-}$subgroup of MCF-7 cells following radiotherapy with the $\mathrm{CHK} 1 / 2$ signal pathway. Radiotherapy increased the population of CD $44^{+} \mathrm{CD} 24^{-}$MCF-7 cells, which was positively correlated with radiation dose and culture time $(\mathrm{P}<0.05)$. With the application of $\mathrm{DBH}$, the dosing of $\mathrm{CD} 44^{+} \mathrm{CD} 24^{-}$cells reduced following radiotherapy from $3.08 \pm 0.41 \%$ to $2.52 \pm 0.34 \%$, which is a reduction of $18.18 \%$. This result indicated that the $\mathrm{CHKl} / 2$ inhibitor DBH reduced the stem cell population of MCF-7. The inhibition by DBH of the $\mathrm{CD} 44^{+} \mathrm{CD} 24^{-}$stem cell population increased significantly in a time-dependent manner until the eighth day and then reduced until $64.45 \%$ was reached.

The proliferation of the $\mathrm{CD} 44^{+} \mathrm{CD} 24$ group cells was suppressed following the inhibition of CHK1/CHK2. This result indicates that the ATM/ATR-CHK1/CHK2-CDC 25A/25B/25C cell cycle checkpoint arm may be important in MCF-7 cancer stem cell population radiation resistance. It may also be compared with other cell subsets. More extensive activation of DBH inhibition may reverse its $\mathrm{CHKl} / 2$ activation following radiotherapy resistance. It is of note that $\mathrm{CD} 44^{+} \mathrm{CD} 24^{-}$cells in the experiment may not be separated completely because of the limited separation methods used. Combined application of immunomagnetic beads, flow cytometry, and other marker, such as antibodies, to label the breast stem cell cluster may results in a more precise conclusion. Studies using serum plus growth factor $\mathrm{CD} 44^{+} \mathrm{CD} 24$ cells in vitro have been previously reported; however, separate cell culture conditions are more demanding.

CSC theory introduced a new tumour formation mechanism to improve understanding of tumour development and prognosis. The results of the present study may serve as a novel theoretical foundation for therapeutic targets, which has important clinical significance. Focusing on cell cycle checkpoint, the target $\mathrm{CHK1} / 2$ may have a potential to reduce CSC resistance to radiation. However, CSC research remains in its infancy, and numerous problems are still encountered. Previous studies have also investigated the CHK signal pathway with cancer stem lines using siRNA technique or gene analysis $(16,34)$.

\section{Acknowledgements}

The present study was approved by the International Review Board of Soochow University (Suzhou, China)and funded by the Second Affiliated Hospital of Soochow University Preponderant Clinical Discipline Fund (grant no. XKQ2015008; awarded to Dr Guo-Qin Jiang).

\section{References}

1. Fillmore CM and Kuperwasser C: Human breast cancer cell lines contain stem-like cells that self-renew, give rise to phenotypically diverse progeny and survive chemotherapy. Breast Cancer Res 10: R25, 2008.

2. Nguyen NP, Almeida FS, Chi A, Nguyen LM, Cohen D, Karlsson U and Vinh-Hung V: Molecular biology of breast cancer stem cells: Potential clinical applications. Cancer Treat Rev 36: 485-491, 2010.

3. Pajonk F, Vlashi E and McBride WH: Radiation resistance of cancer stem cells: The 4 R's of radiobiology revisited. Stem Cells 28: 639-648, 2010.

4. Kai K, Arima Y, Kamiya T and Saya H: Breast cancer stem cells. Breast Cancer 17: 80-85, 2010.

5. Al-Hajj M, Wicha MS, Benito-Hernandez A, Morrison SJ and Clarke MF: Prospective identification of tumorigenic breast cancer cells. Proc Natl Acad Sci U S A 100: 3983-3988, 2003.

6. Sheridan C, Kishimoto H, Fuchs RK, Mehrotra S, Bhat-Nakshatri P, Turner $\mathrm{CH}$, Goulet $\mathrm{R}$ Jr, Badve $\mathrm{S}$ and Nakshatri H: CD44 /CD24- breast cancer cells exhibit enhanced invasive properties: An early step necessary for metastasis. Breast Cancer Res 8: R59, 2006.

7. Shipitsin M, Campbell LL, Argani P, Weremowicz S, Bloushtain-Qimron N, Yao J, Nikolskaya T, Serebryiskaya T, Beroukhim R, Hu M, et al: Molecular definition of breast tumor heterogeneity. Cancer Cell 11: 259-273, 2007.

8. Hwang-Verslues WW, Kuo WH, Chang PH, Pan CC, Wang HH, Tsai ST, Jeng YM, Shew JY, Kung JT, Chen CH, et al: Multiple lineages of human breast cancer stem/progenitor cells identified by profiling with stem cell markers. PLoS One 4: e8377, 2009.

9. Harper JW and Elledge SJ: The DNA damage response: Ten years after. Mol Cell 28: 739-745, 2007.

10. Ackerstaff E, Glunde K and Bhujwalla ZM: Choline phospholipid metabolism: A target in cancer cells? J Cell Biochem 90: 525-533, 2003.

11. Ramírez de Molina A, Gutiérrez R, Ramos MA, Silva JM, Silva J, Bonilla F, Sánchez JJ and Lacal JC: Increased choline kinase activity in human breast carcinomas: Clinical evidence for a potential novel antitumor strategy. Oncogene 21: 4317-4322, 2002.

12. Glunde K, Ackerstaff E, Natarajan K, Artemov D and Bhujwalla ZM: Real-time changes in $1 \mathrm{H}$ and 31P NMR spectra of malignant human mammary epithelial cells during treatment with the anti-inflammatory agent indomethacin. Magn Reson Med 48: 819-825, 2002. 
13. Hernández-Alcoceba R, Saniger L, Campos J, Núñez MC, Khaless F, Gallo MA, Espinosa A and Lacal JC: Choline kinase inhibitors as a novel approach for antiproliferative drug design. Oncogene 15: 2289-2301, 1997.

14. Rodríguez-González A, Ramirez de Molina A, Fernández F and Lacal JC: Choline kinase inhibition induces the increase in ceramides resulting in a highly specific and selective cytotoxic antitumoral strategy as a potential mechanism of action. Oncogene 23: $8247-8259,2004$

15. Glunde K, Raman V, Mori N and Bhujwalla ZM: RNA interference-mediated choline kinase suppression in breast cancer cells induces differentiation and reduces proliferation. Cancer Res 65: 11034-11043, 2005.

16. Bensimon J, Altmeyer-Morel S, Benjelloun $\mathrm{H}$, Chevillard S and Lebeau J: CD24(-/low) stem-like breast cancer marker defines the radiation-resistant cells involved in memorization and transmission of radiation-induced genomic instability. Oncogene 32: 251-258, 2013.

17. Curman D, Cinel B, Williams DE, Rundle N, Block WD, Goodarzi AA, Hutchins JR, Clarke PR, Zhou BB, Lees-Miller SP, et al: Inhibition of the G2 DNA damage checkpoint and of protein kinases chkl and chk2 by the marine sponge alkaloid debromohymenialdisine. J Biol Chem 276: 17914-17919, 2001.

18. Su WY and Gordon T: In vivo exposure to ozone produces an increase in a $72-\mathrm{kDa}$ heat shock protein in guinea pigs. J Appl Physiol (1985) 83: 707-711, 1997.

19. Dittmann K, Mayer C,Fehrenbacher B, Schaller M, Raju U, Milas L, Chen DJ, Kehlbach R and Rodemann HP: Radiation-induced epidermal growth factor receptor nuclear import is linked to activation of DNA-dependent protein kinase. J Biol Chem 280 : 31182-31189, 2005.

20. Marín L, Minguela A, Torío A, Moya-Quiles MR, Muro M, Montes-Ares O, Parrado A, Alvarez-López DM and García-Alonso AM: Flow cytometric quantification of apoptosis and proliferation in mixed lymphocyte culture. Cytometry A 51: 107-118, 2003.

21. Chen MS, Woodward WA, Behbod F, Peddibhotla S, Alfaro MP, Buchholz TA and Rosen JM: Wnt/beta-catenin mediates radiation resistance of Sca ${ }^{+}$progenitors in an immortalized mammary gland cell line. J Cell Sci 120: 468-477, 2007.

22. Woodward WA, Chen MS, Behbod F, Alfaro MP, Buchholz TA and Rosen JM: WNT/beta-catenin mediates radiation resistance of mouse mammary progenitor cells. Proc Natl Acad Sci USA 104: 618-623, 2007.

23. Sansone P, Storci G, Giovannini C, Pandolfi S, Pianetti S, Taffurelli M, Santini D, Ceccarelli C, Chieco P and Bonafé M p66Shc/Notch-3 interplay controls self-renewal and hypoxia survival in human stem/progenitor cells of the mammary gland expanded in vitro as mammospheres. Stem Cells 25: 807-815, 2007.
24. Sancar A, Lindsey-Boltz LA, Unsal-Kacmaz K and Linn S: Molecular mechanisms of mammalian DNA repair and the DNA damage checkpoints. Annu Rev Biochem 73: 39-85, 2004.

25. Xiao Z, Xue J, Semizarov D, Sowin TJ, Rosenberg SH and Zhang H: Novel indication for cancer therapy: Chkl inhibition sensitizes tumor cells to antimitotice. Int J Cancer 115: 528-538, 2005

26. Wang HC, Chou WC, Shieh SY and Shen CY: Amtaxia telangiectasia mumted and checkpoint kinase 2 regulate BRCA1 to promote the fidelity of DNA end-joining. Cancer Res 66: 1391-1400, 2006.

27. Zhuang J, Zhang J, Willers H, Wang H, Chung JH, van Gent DC, Hallahan DE, Powell SN and Xia F: Checkpoint kinase 2-mediated Phosphoryiation of BRCAl regulates the fidelity of nonhomologous end-joining. Cancer Res 66: 1401-1408, 2006.

28. Tan Y, Raychaudhuri P and Costa RH: Chk2 medistes stabilization of the FoxM1 transcription factor to stimulate expression of DNA repair genes. Mol Cell Biol 27: 1007-1016, 2007.

29. Arienti KL, Brunmark A, Axe FU, McClure K, Lee A, Blevitt J, Neff DK, Huang L, Crawford S, Pandit CR, et al: Checkpoint kinase inhibitors: SAR and radioprotective properties of aseries of 2-arylbenzimidazoles. J Med Chem 48: 1873-1885, 2005.

30. Bull EE, Dote H, Brady KJ, Burgan WE, Carter DJ, Cerra MA, Oswald KA, Hollingshead MG, Camphausen K and Tofilon PJ: Enhanced tumor cell radiosensitivity and a btogation of $\mathrm{G} 2$ and $\mathrm{S}$ phase arrest by the Hsp90 inhibitor 17-(dimethylaminoethylamino)-17-demethoxygeldanamycin. Clin Cancer Res 10: 8077-8084, 2004.

31. Kastan MB and Bartek J: Cell-cycle checkpoints and Cancer. Nature 432: 316-323, 2004

32. Lee JH and Paull TT: ATM activation by DNA double-strand breaks through the Mrell-Rad50-Nbs1 complex. Science 308: 551-554, 2005.

33. Reya T, Morrison SJ, Clarke MF and Weissman IL: Stem cells, cancer and cancer stem cells. Nature 414: 105-111, 2001.

34. Shah T, Wildes F, Penet MF, Winnard PT Jr, Glunde K, Artemov D, Ackerstaff E, Gimi B, Kakkad S, Raman V and Bhujwalla ZM: Choline kinase overexpression increases invasiveness and drug resistance of human breast cancer cells. NMR Biomed 23: 633-642, 2010. 